\title{
MICRO-APARTMENT IN PONTIANAK
}

\author{
Al-yakoob Dania', Zairin Zain², Valentinus Pebriano ${ }^{3}$ \\ ${ }^{1}$ Student of Architecture department, Engeneering Faculty, Universitas Tanjungpura \\ alyakoobdania@student.untan.ac.id \\ ${ }^{2}$ Architecture Departement, Engeneering Faculty, Universitas Tanjungpura \\ ${ }^{3}$ Architecture Departement, Engeneering Faculty, Universitas Tanjungpura
}

Manuscript submitted on: 18 February 2021

Final revised manuscripts received on: 21 February 2021

\begin{abstract}
As the world population, the majority of Indonesian's town all knows an increase of their population that results in an augmentation of the housing needs. What is called Micro-housing is a new global trend that targets a younger worker part of the population and also a newly married couple that doesn't have children yet. Indeed, this part of the population is in need to find house or apartment close to their workplace, close to the transportation of the city but also close to all the other town facilities like hospitals, restaurant, stores. This desire of finding a house or apartment in a strategic location known as the center of a town tends to increase but the available spaces to build more houses tend to decrease. That is why one of the solutions to this space problem is micro-housing; this type of new housing will allow responding to this problem of available space. This design project is not only about reducing space, but it is also focus on being able to design and create a layout space that responds to the multiple needs of the tenant by using multiple techniques in the design layout but also using transformable and foldable pieces of furniture.
\end{abstract}

Keywords: Micro-housing, reduced space, sustainable

\begin{abstract}
Abstrak
Sebagai penduduk dunia, mayoritas penduduk kota di Indonesia mengetahui adanya peningkatan jumlah penduduk yang berakibat pada bertambahnya kebutuhan akan perumahan. Apa yang disebut Micro-housing adalah tren global baru yang menargetkan pekerja yang lebih muda dari populasi dan juga pasangan yang baru menikah yang belum memiliki anak. Memang bagian dari populasi ini membutuhkan untuk mencari rumah atau apartemen yang dekat dengan tempat kerja mereka, dekat dengan transportasi kota tetapi juga dekat dengan semua fasilitas kota lainnya seperti rumah sakit, restoran, pertokoan. Keinginan untuk mencari rumah atau apartemen di lokasi strategis yang dikenal dengan pusat kota cenderung meningkat namun ketersediaan ruang untuk membangun lebih banyak rumah cenderung berkurang. Itulah mengapa salah satu solusi untuk masalah ruang ini adalah rumah mikro; jenis perumahan baru ini akan memungkinkan untuk menanggapi masalah ruang yang tersedia. Proyek desain ini tidak hanya tentang mengurangi ruang, tetapi juga fokus pada kemampuan untuk merancang dan membuat ruang tata letak yang menanggapi berbagai kebutuhan penyewa dengan menggunakan beberapa teknik dalam tata letak design tetapi juga menggunakan furnitur yang dapat diubah dan dilipat.
\end{abstract}

Kata-kata kunci: Perumahan mikro, ruang terbatas, berkelanjutan

\section{Introduction}

According to the estimation made by the US Bureau of the Census (2019), the world population increased by more than 246000 million inhabitants per day during 2016. During this year, the world population knows a significant growth and at the same time, the needs of houses follow the same increase. The most basic one of those needs is the request of owning a shelter, a home, a house, or simply a place to live (Patton, 1988). If we observe the current economic and demographic changes, we can perceive a high demand in the real estate market all around the world. 
Micro-housing seems to have a lot of potential in solving and/or diminishing the current housing problem (Jones, 2017). A study performed by Potikyan (2017) stipulates that only $40 \%$ of all available space inside a house is frequently used, that is why a more minimalist house or apartment can provide the same comfort and necessary living space on a smaller surface like a micro-housing. That will help to avoid a waste of almost $60 \%$ of the living space. According to Gabbe (2015) "this new type of housing [micro-housing] also provides affordable living places in a central location that are frequently searched." However, micro-apartments represent only a small part of the housing development and urbanization. In a city, especially downtown and the urban area tends to attract a large number of young people such as young careerist, stay over commuter and workforces toward those areas, this is a gentrification type called the youthification (Florida, 2019). Unfortunately, downtown city areas are without a doubt a limited space that can't be expanded. Urban areas are more attractive due to the presence of facilities, hospital, etc (Waite, 2015).

The Indonesian population keeps increasing by following the same path indeed during the year 2000 to 2010 there was an augmentation from 205.1 million to 237.6 million habitants, this represents a $1.49 \%$ augmentation in ten years. Based on statistics made by the long term if this demand isn't correctly managed it will create trouble to find enough space to locate all these new inhabitants (Central Bureau of Statistic, 2019). There are some cities like Jakarta that already face issues about offering affordable and efficient living spaces. Pontianak is the capital of West Kalimantan located on Borneo Island. Demographically the population in this town is increasing and if left unsupervised will lead to the same needs of more shelter or homes discussed earlier. Indeed according to the statistic made by the Central Bureau of Statistics of Pontianak (2019), the number of residents in Pontianak increased significantly each year: in 1990 the population total was 431.328 people, and within 10 years, in 2000 , this number became 464.534 people: the growth of 7.7 percent. Then in 10 years, in 2010 it became 554.764 people, all those numbers can be translated by $19.42 \%$ of growth.

The design of Micro-apartment in Pontianak will be focused on the creating of a space allowing the tenant to feel safe and comfortable by providing them a small functional space that still possessed a connection to the others. The trend toward smaller apartments could have a bigger impact beyond that on the actual residents who opt to trade square footage for the chance to live solo in happening (Said, 2013). This design will be a functional and comfortable solution to a near demographic issues.

\section{Literature Review}

Based on the literature, we can find that there is no set definition for a micro-apartment, the size of one micro-unit isn't fixed and can vary in function of the city regulation, the typical size of a micro-apartments is proportional to the size of a studio. This can be translated as a city with large apartment standard will have a larger size for their micro- apartments. Micro-apartments can be considered as the same size of a studio apartment, the size varying from 14 to $32 \mathrm{~m}^{2}$. Even though there is no standard in the size of those, there are still common points between micro-apartments such as the presence of multi-functional built-in furniture and storage systems that help make the space more functional (Urban Land Institute, 2017). Additionally to the furniture and storage space, still according to the Urban Land Institute (2017) explain that micro apartment is usually made with large windows and high ceilings, this will trick the perception of the tenant and make the apartment seems larger than it is. Also, the fact that space is reduced as much as possible implies that the tenant of the apartment will have to use the same space for several different activities, Sullivan and Chen (1997) calls it a multipurpose space.

According to Pandhi (2017) furniture is considered by most to be a necessity and not a luxury. By definition, furniture is a piece of large movable equipment, such as tables and chairs that are, put into a house or other building to make it suitable and comfortable for living or working in it. 
Apartments are getting smaller day by day, which implies smaller space to keep all the furniture necessary for a comfortable life. That also means that a micro-apartment can no longer hold standard size furniture like bed, table, couch. Micro-apartments only have enough space to hold smart furniture to preserve a maximum of space to circulate. In a regular size apartment, basic furniture like a bed, sofa, chairs, and table usually covers around 40 to $50 \%$ of the total floor space. The issue can be solved by some smart solutions like multifunctional furniture, modular furniture, and well-designed space, they all increase space efficiency (Estaji, 2017) It's important to be able to understand the needs of the tenant of a small apartment to select accurately the furniture that we want to include inside the micro-apartment. A data survey shows the main furniture used in small apartments and space their filling: for examples, a bed takes up around 93\% of the bedroom space, sofa chair, and table takes up around $60 \%$ of the living space (Thogersen, 2017).

\section{Method}

This design uses the Robert Whitaker design method which consists of the introduction stage, the definition stage, the preparation stage, the analysis stage, the synthesis stage, the evaluation stage, and the re-evaluation stage (Snyder \& Catanese, 1989). First, the introduction stage begins with related issues which are the reasons for the construction of micro-housing in Pontianak. The definition stage is based on the background of the problem by reading circulating news about micro-housing, literature studies, and data about micro-housing. The preparation stage is to collect primary data obtained from existing site observations and interviews with weavers in Pontianak City and collect secondary data obtained from literature and case studies. The analysis stage is obtained to find solutions to problems that include function analysis, factor analysis, space analysis, location analysis, site analysis, shape analysis, structural analysis, utility analysis, and building physics analysis. The synthesis stage is a concept description that produces a schematic of outer and inner space as well as three-dimensional shapes that explain the application of shape, structure, utility, and building physics analysis. The evaluation stage is the stage of compiling the design and planning concept. The re-evaluation stage is the stage of re-examining the final results of the documentation, namely pre-designed drawings, architectural plans, structural plans, utility plans.

\section{Results and Discussion}

The location of the design of Micro-housing is located on the road Hijas, Benua Melayu Darat Village, South Pontianak District, Pontianak Municipality. Kalimantan Province, West Kalimantan. For this area, the BCR is $80 \%$, FAR is 3.2 , and GOS is $30 \%$. 


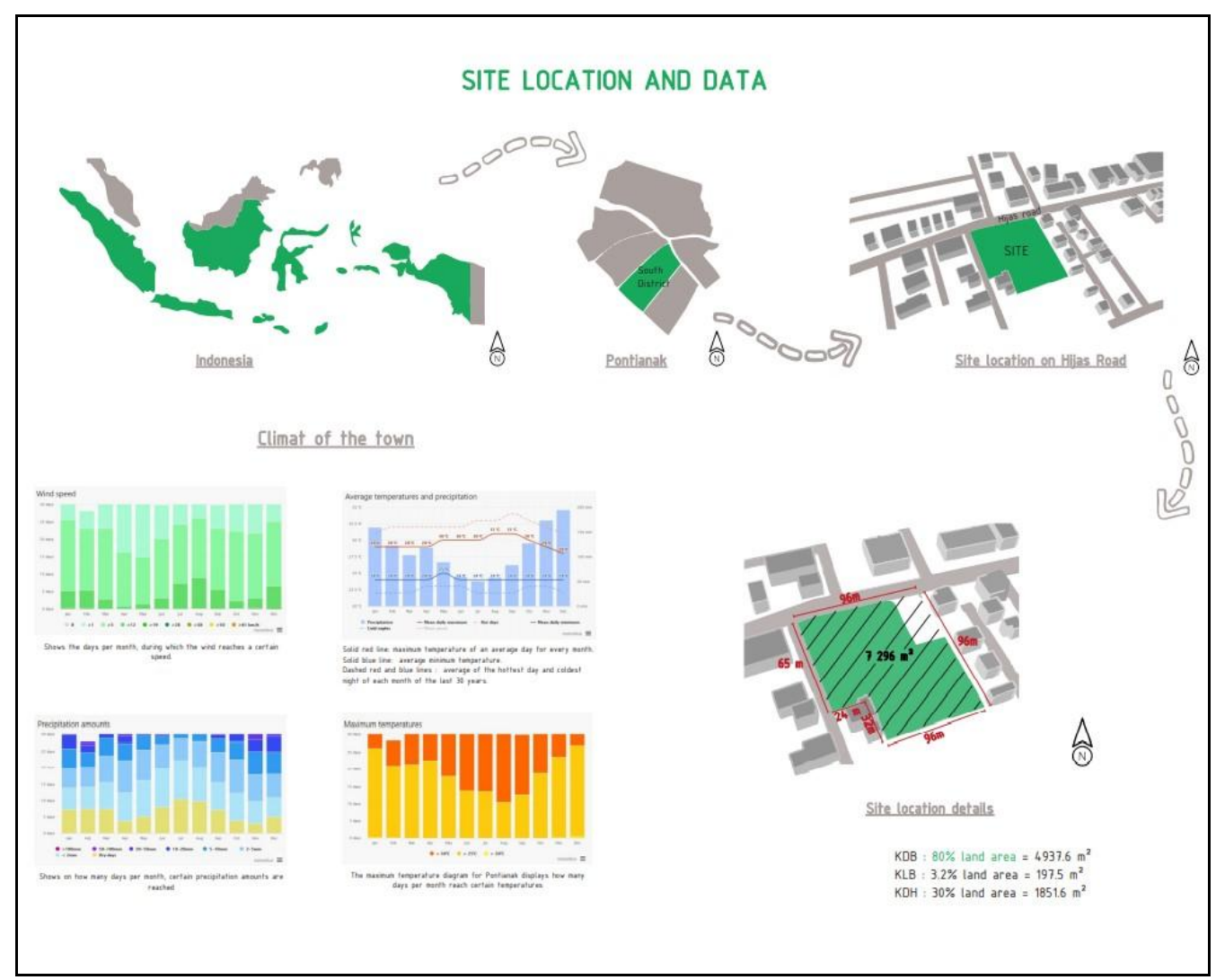

Figure 1. Location of the design of Micro-Apartment in Pontianak

Sources: Author, 2020

\section{Main Concept}

The conceptual basis resulted in the planning and design concepts of Micro-apartment in Pontianak. The initial process of analysis is the identification of the problem to find a solution. The function of the micro-apartment is formulated based on theories regarding the activities related to the housing in Pontianak inWest Kalimantan. Micro-apartment being a type of housing possessed function that is similar to a house, which is: [a house is a] support for the family identity, support for the family development socio-cultural opportunity and support the family by giving a sense of security according to Turner and Jogn (1972:164-167), The user of the design of Micro-apartment in Pontianak is composed of three major groups. The users of a residential building are the residents, their guests, and the maintenance team. The residents: are the tenant of the microapartments of the building, this group is composed of men and women workers aged in a range between 24 and 35 years old.

The guest: is composed of the friends of the tenant, contrary to the resident, the age range of the guest is quite wide, starting from newborn to older people. The maintenance team: or maintenance staff is composed of the cleaning staff, security staff, and technical staff. Those teams are here to help do the maintenance of the building facilities, keep the guests and residents safe and also keep the common facilities clean. There are three categories of room requirements for the design of Micro-apartment in Pontianak. The first one is the communal spaces and service spaces composed of 8 rooms like lobby, multifunctional room, prayer room, mailbox, lift room, trashbin room, and parking. The second space category is the service area, composed of 12 rooms like a police post, water pump room, Genset room, panel room, sound system and CCTV room, STP area, VRV engine room, GWT area, janitor public toilet, and warehouse. The third space category is composed of three types of unit, unit type A is composed of 5 space, bathroom, kitchen, balcony, guest room, and bedroom, there are 74 unit type A, so a total of 120 room. The second unit type B 
is composed of 4 rooms, bathroom, kitchen, balcony, and bedroom there are a total of 74 units B so a total of 96 rooms. The third unit type $\mathrm{C}$ is composed of 4 rooms, bathroom, kitchen, balcony, and bedroom there are a total of 74 units $\mathrm{C}$ so a total of 96 rooms. The design of Micro-apartment in Pontianak is composed of 332 rooms. In resume the surface area of the sign is composed of 4 $297.50 \mathrm{~m}^{2}$ for the total area of the building, a total of $6016.5 \mathrm{~m}^{2}$ for the area total including (40\%) the open spaces. Analysis of the site of Micro-housing in Pontianak is divided into zoning, orientation, circulation, placement, and vegetation.

Zoning, placing a public zone is located at the north part of the site. The semi-public zone is in the middle northwest part of the site. The semi-private zone is located at the southeast part of the site. The private zone is located in the southeast, where noise levels are low. The service zone is located in the southwest part of the site. The parking is located under the three masses. As seen on Figure 2. The orientation of the building is toward the north part of the site. This orientation helps to offer a view of the main adjacent street and also to facilitate the entry and of the vehicles on the site. The circulation is composed of two main paths. The first path is the vehicle's one, which is located on the ground level, the entry and exit are located at the north part of the site. The second part of the site is located on the second horizontal level, level 1. This is the circulation path for pedestrians. As seen on Figure 3. The placement of the building mass of the design of Microapartment in Pontianak is separated into three, one masse a the northeast of the site, one at the southeast, and the last one at the west part of the site. Each mass is composed of the same elements, semi-basement parking lots, podium, pedestrian area, and micro-apartments buildings. As seen on Figure 4.

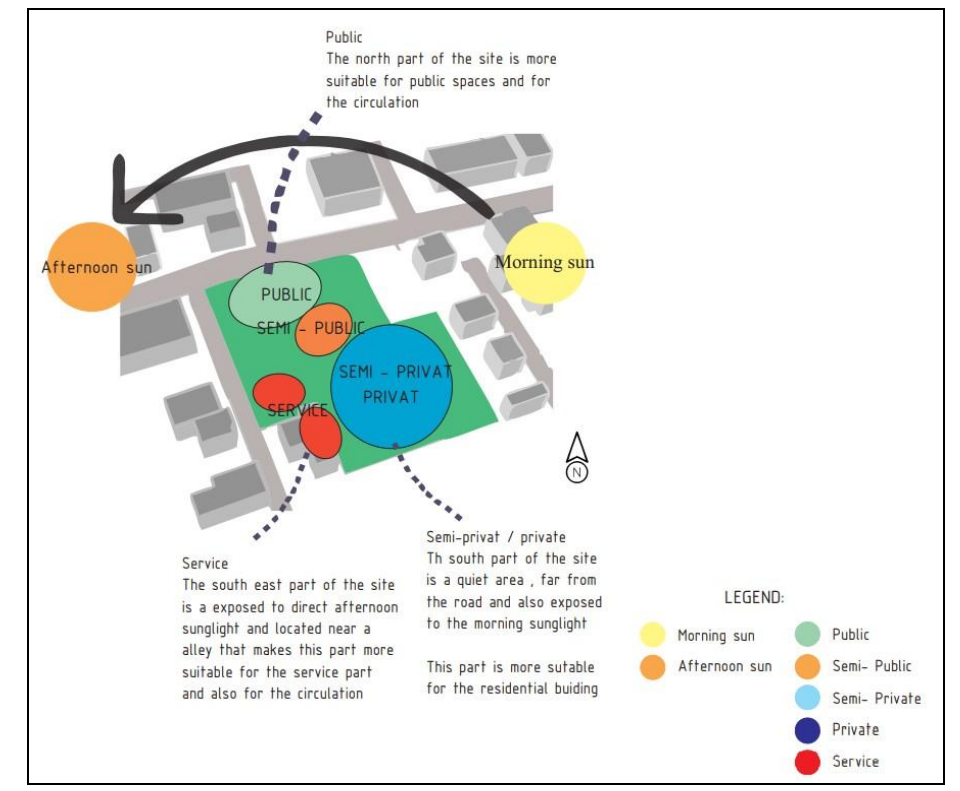

Figure 2. Zoning Site Analysis of the design of Micro-Apartment in Pontianak Sources: Author, 2020 


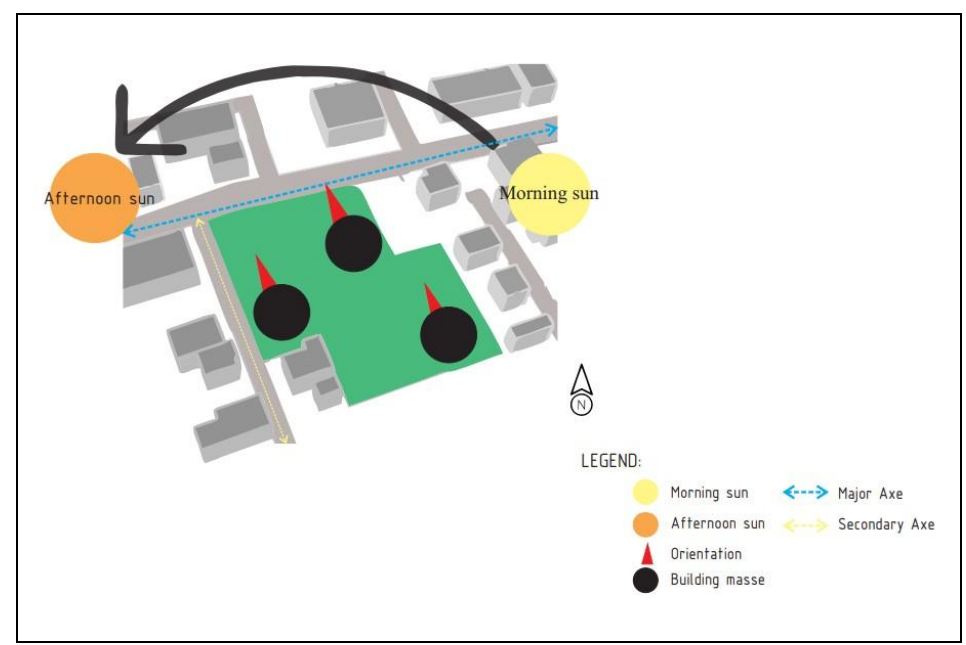

Figure 3. Circulation and Orientation Site Analysis of the design of Micro-Apartment in Pontianak Sources: Author, 2020

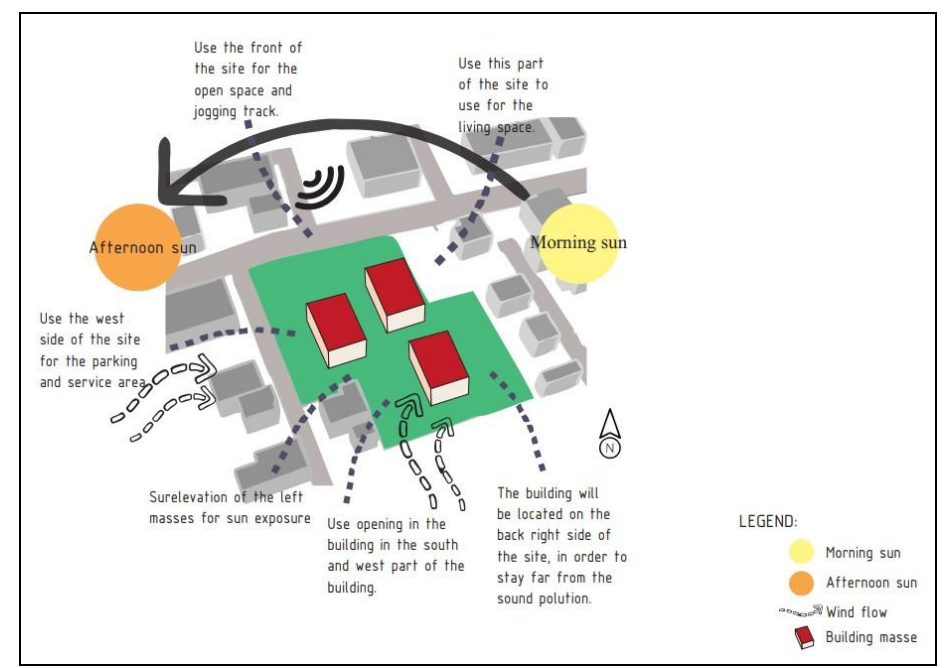

Figure 4. Position Site Analysis of the design of Micro-Apartment in Pontianak Sources: Author, 2020

The mass composition of Micro-apartment in Pontianak is a direct application of an internal and external analysis. The masse composition also takes into count contemporary architectural approaches toward basic shapes, facades, and landscape design.

The composition concept of Micro-apartment in Pontianak applies the basic formation idea from the analogy of the horizontal stratification of the Borneo rainforest. The semi-basement parking came from the horizontal shrub layer of the forest that represents the place where light isn't thick. The pedestrian area represents and the micro-apartment building represents the canopy layer of the forest, that is the place where the habitant is, the pedestrian area shapes creates connection like the liana of the trees. The secondary skin that is located on the building is the representation of the emergent layer that is composed of tree foliage, the secondary skin is inspired by this foilage.

The structure concept of Micro-apartment in Pontianak uses a structure module of $6 \times 6$ for the semi-basement part and a structure module of $6 \times 4$ for the building part. This design uses a system of pile foundation due to the type of soil. The construction of the floor is cast in concrete covered with ceramic floor tile. The utility concept Micro-apartment in Pontianak includes a water network system, an electricity system, an air conditioning network system, a building security system, and a solid waste system. The clean water network system uses a down feed system. There are 3 groundwater tanks (GWT), one for each mass. The dirty water goes from the sanitary to the STP 
area. The wastes like dirt are collected in a septic tank and then brought toward the STP and then toward the city sewage system. The electrical network system is composed of lightning installation, in the design of Micro-apartment in Pontianak, the light used are LED lightning. For the CCTV network, this design used small CCTV units. The communication system of the building is divided between the internet network and the telephone network. The internet network installation is using wifi by the mean of a router. The telephone installation is made by a public network then distributed to the PABX of the building en then redistribute to the units.

The ventilation system of Micro-apartment in Pontianak is divided in two-part, artificial ventilation system and natural ventilation The artificial ventilation system is composed of an air condition system named VRV (stand for variable refrigerant volume), the benefits of this system is its relative small dimension, this is used for the indoor units. The natural ventilation of the building is made through the uses of rooster wall an opening located in the communal part of the building like staircases. The building system security system is composed of lightning rod protection and fire protection system. In this design the building is using an Early Streamer system located on top of the building, the advantage of this type protects the building on a large radius. The fire protection of the building is composed of an active and passive system. The active protection system is composed of smoke detectors, light fire extinguishers (APAR), building hydrant, and sprinklers. The passive protection system is composed of a way to escape, fire damper, fire retardant, reinforced concrete used for the staircase.

The building physic concept of the design of Micro-apartment in Pontianak is composed of the ventilation system, lighting system, and acoustic system. The natural ventilation system is used in the design by the use of a rooster wall in the communal space of the building, which creates an effect of cross ventilation. The apartment unit is equipped with air-conditioner unit that offers comfort for the user. Natural lighting is favored in the design of this building and is translated by the use of multiple large windows in the room and the common spaces like the staircases and lobby area, this allows maximum use of the daylight lightning. The parking lot is located under the podium but its semi-buried, the wall of the semi-basement parking is composed of multiple windows that help to reduce the use of artificial lighting during the daytime. The acoustic application to this design of the apartment is created by the uses of buffer vegetation and also by the layering of soundproof material such as acoustic coating and floor underlayment.

\section{Design Results}

Based on the results of the previous analysis and the concept there are the following predesign figures of the Design of Micro-apartment in Pontianak. The design is composed of three podiums all connected by the pedestrian bridges and also composed of the site area. Each podium is composed of a semi-basement parking, lobby, pedestrian area and three building that includes the micro-apartments. The access and exit of the site are located at the north part of the site. The major road axes create a diagonal from the northwest part of the site to the southeast of the site. Three semi-basement parking lots are located under each podium, in total there are 98 mobile parking spaces, 95 motorcycle parking spaces. The is a special path for the pedestrian that is located on top of the podium and that creates a connection with the three masses by the mean of 4 pedestrian bridges. On top of each parking, there can be found three micro-apartment buildings. 


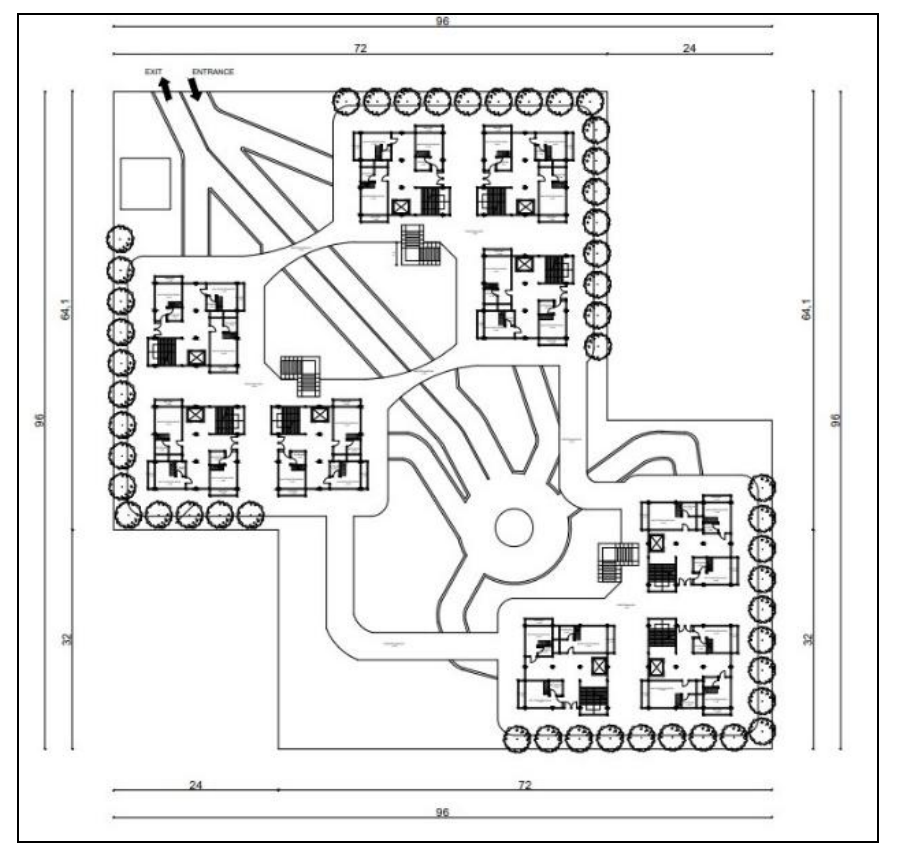

Figure 3. Site Plan of the Design of Micro-Apartment in Pontianak Sources: Author, 2020

The floorplan of the design of micro-apartment in Pontianak starts with the lobby located on level-1. This floor is composed of a communal lobby for all three buildings, a multifunctional room, prayer room, common toilet, trashbin warehouse, three lifts that bring up to the three microapartment building. The first floor is composed of three identical plans for the three buildings, each one of them is composed of one staircase, one lift, one micro-apartment type A, one microapartment type B, and one micro-apartment type $\mathrm{C}$, the second and third floor are all organized in the same way.

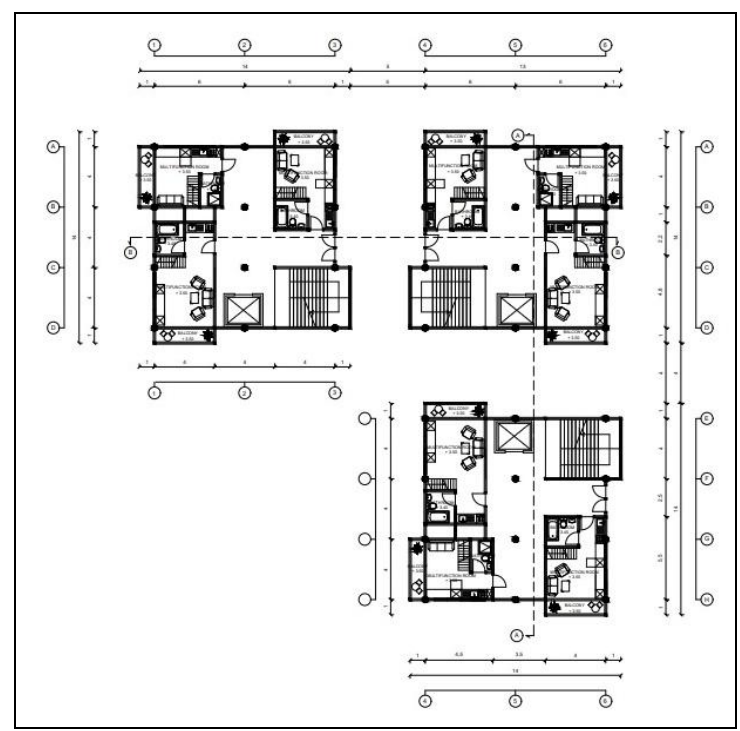

Figure 4. First Floorplan of the design of Micro-Apartment in Pontianak

Sources: Author, 2020 


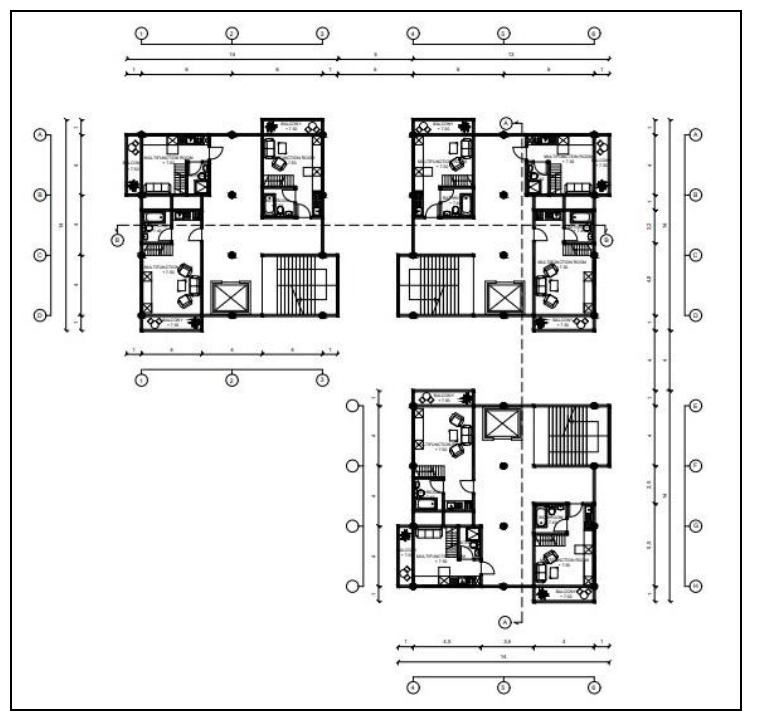

Figure 5. Second Floorplan of the design of Micro-Apartment in Pontianak Sources: Author, 2020

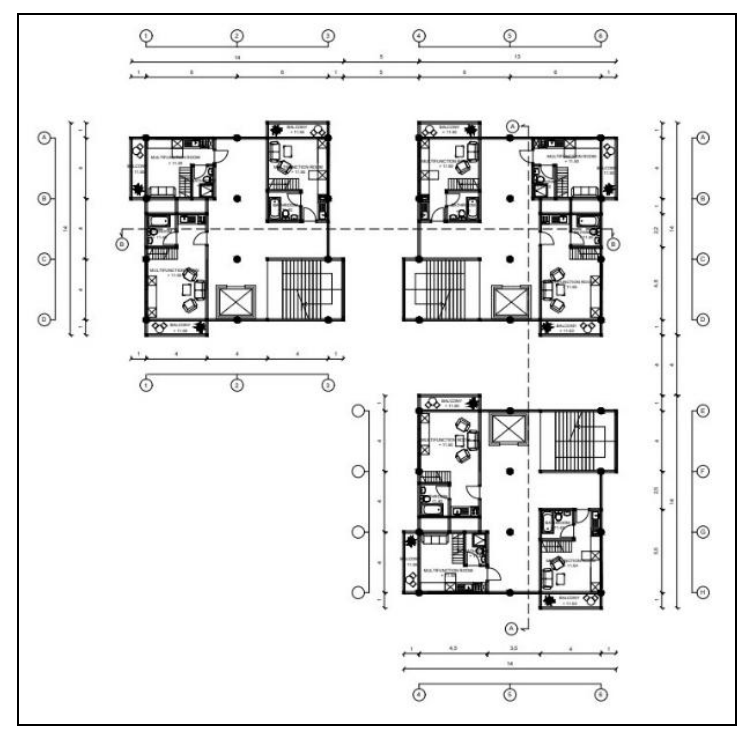

Figure 6. Third Floorplan of the design of Micro-Apartment in Pontianak Sources: Author, 2020

The elevations of the design of Micro-apartment are all composed of the same element, each one of the elevations allows us to see the building from a different perspective allowing us to put in light each time different elements.

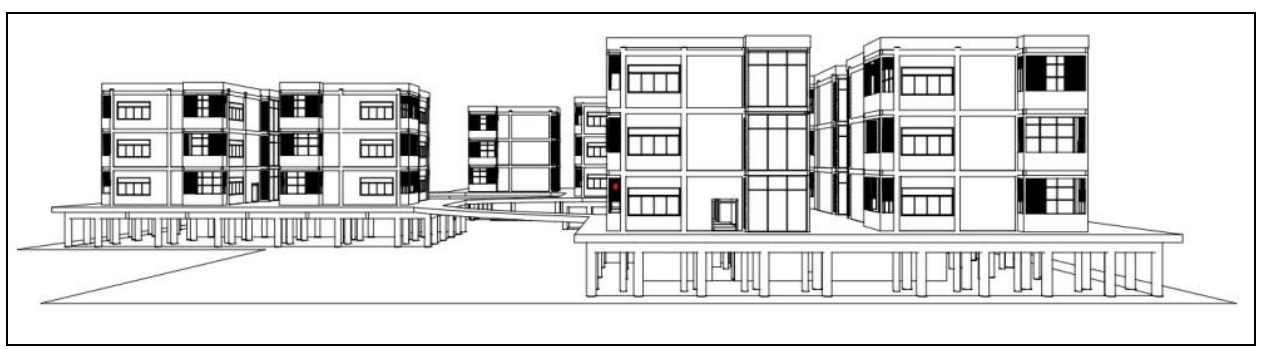

Figure 7. Front Elevation of the design of Micro-Apartement in Pontianak Sources: Author, 2020 


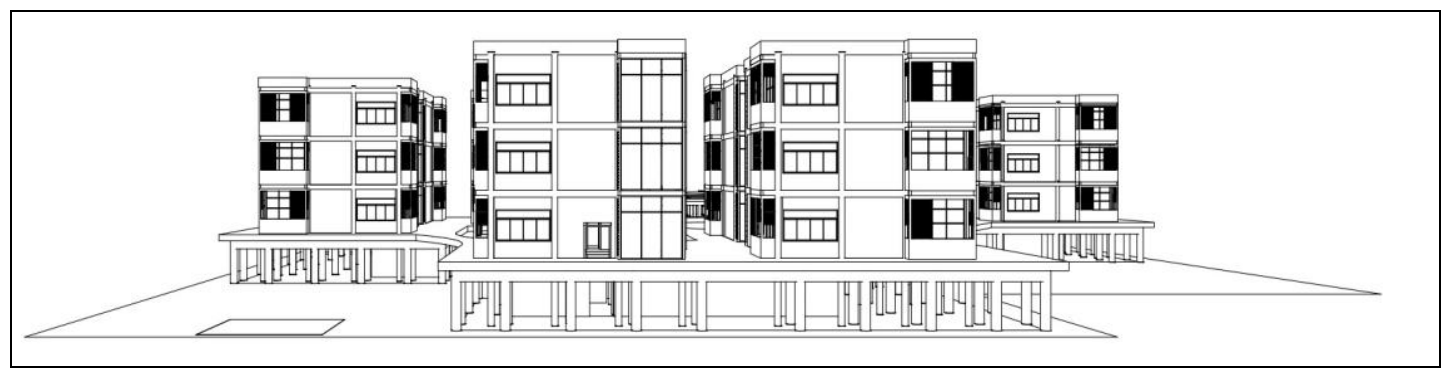

Figure 8. Back Elevation of the design of Micro-Apartment in Pontianak Sources: Author, 2020

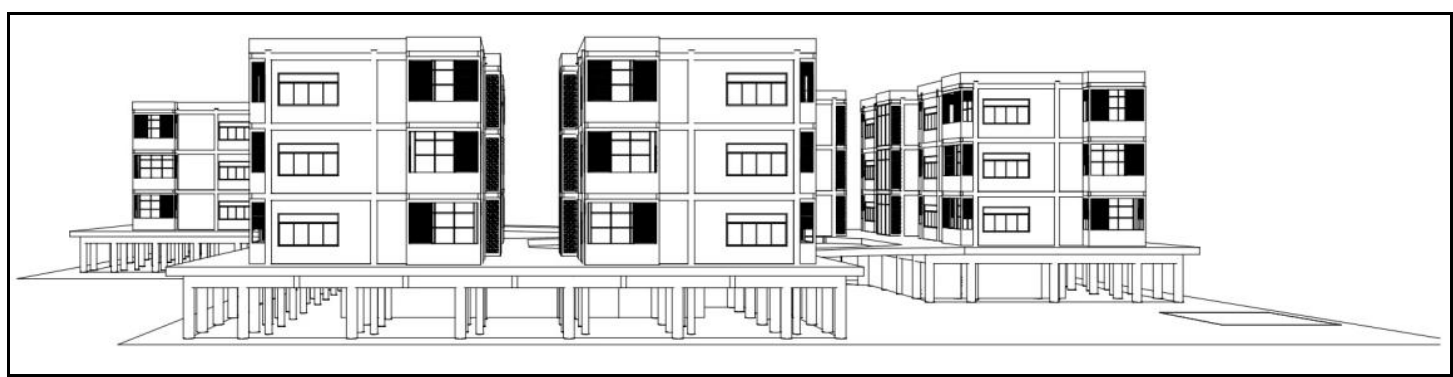

Figure 9. Right Elevation of the design of Micro-Apartment in Pontianak Sources: Author, 2020

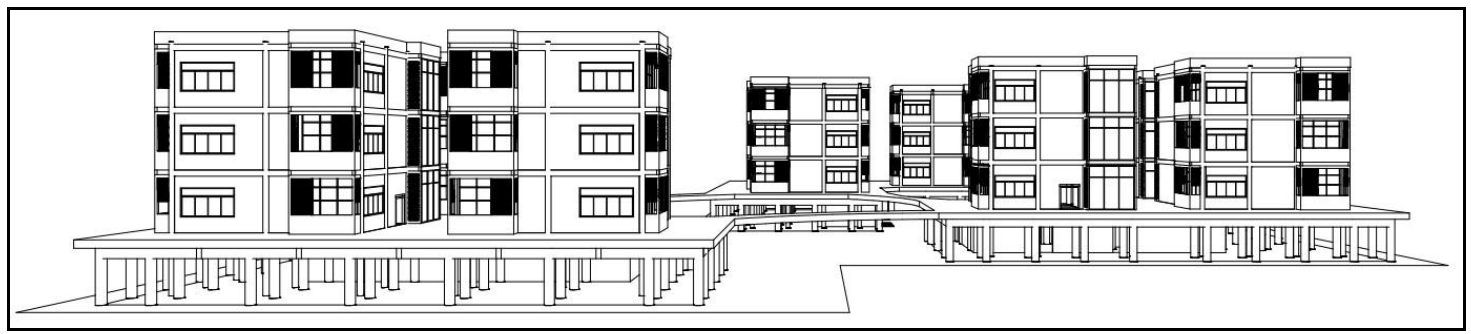

Figure 10. Left Elevation of the design of Micro-Apartment in Pontianak Sources: Author, 2020

The section of the Micro-apartment cuts through the podium, pedestrian area, and two buildings, the A-A and B-B section allows to see the inside and organization of the staircase, apartment living space, and the internal stairs of apartments unit and also the bedroom space located over the bathroom. The sections also allow us to see the structural composition of the pedestrian area and the semi-basement parking and pile foundation.

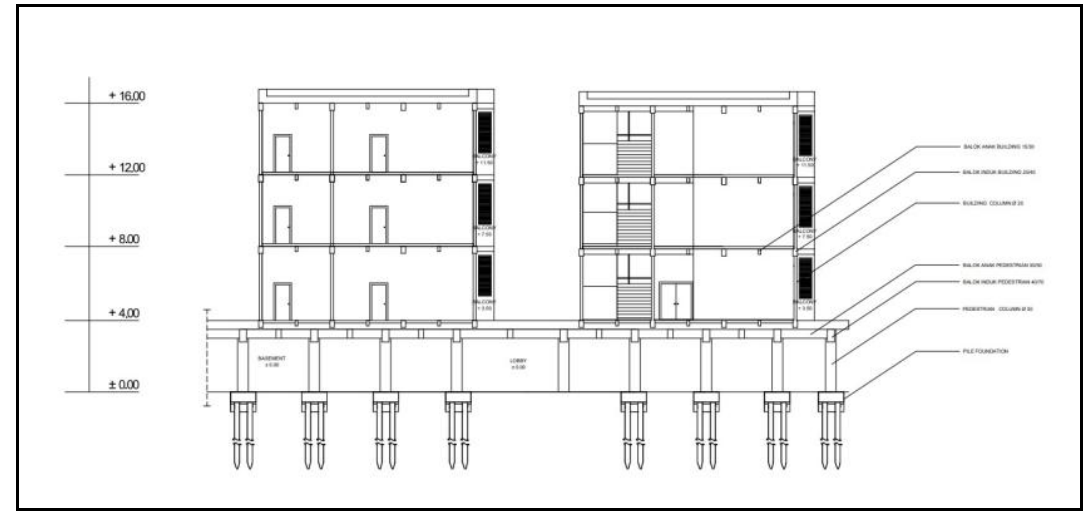

Figure 11. Section A-A of the design of Micro-Apartment in Pontianak Sources: Author, 2020 


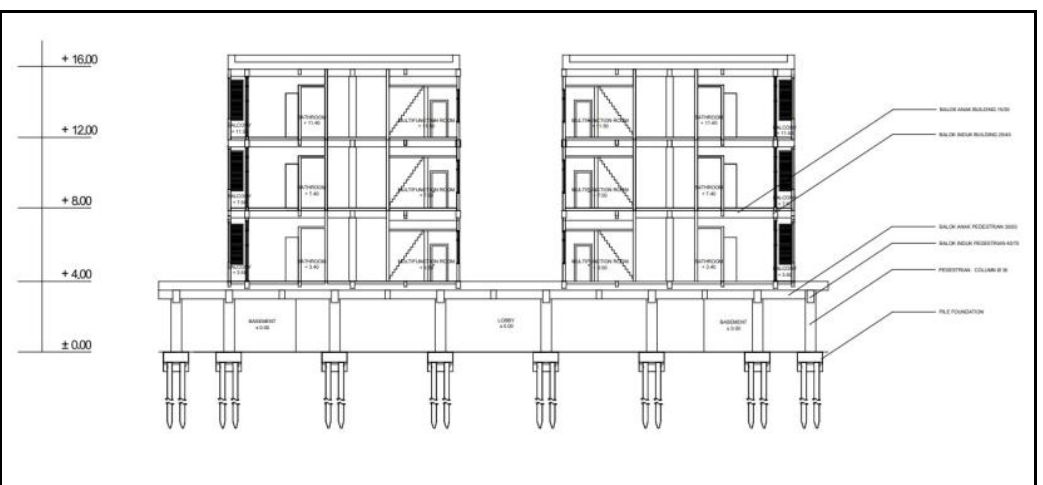

Figure 12. Section B-B of the design of Micro-Apartment in Pontianak

Sources: Author, 2020

The exterior atmosphere shows the number of masses that are located on the site. The exterior of the building is in majority composed of white and wood color elements, the buildings are made of a light color concrete and the four faces of each building are covered in a secondary skin that has a woodish colors.

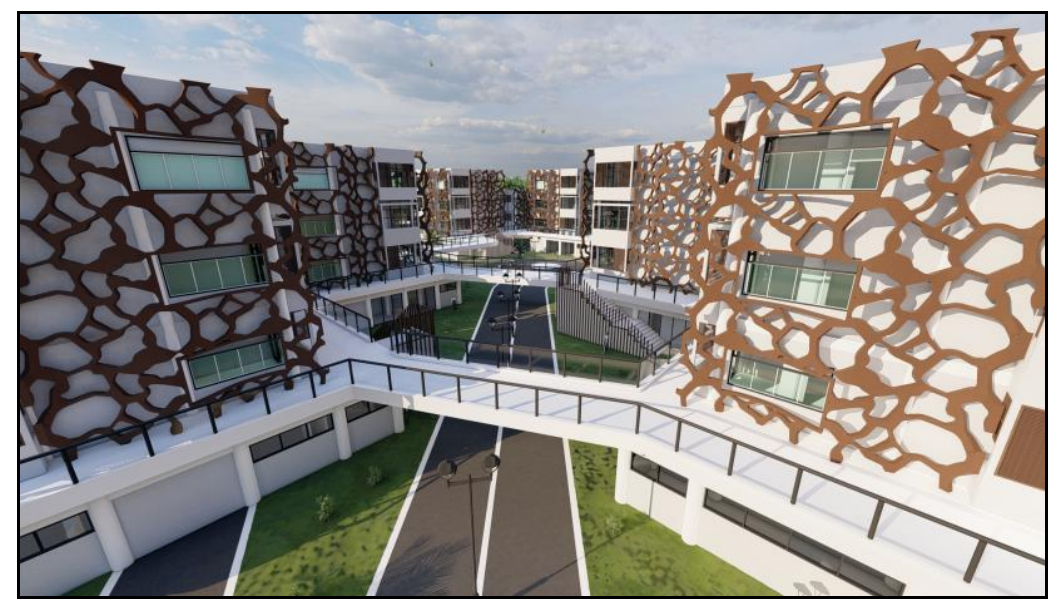

Figure 13. Exterior Atmosphere of the design of Micro-Apartment in Pontianak Sources: Author, 2020

The interior figures show the pedestrian area and also the bridges with their ramps composed of glass and black aluminum. The separation between the living space and bedroom is created through heigh but also from the wall's colors that are darker surrounding the bed to create the sensation of an enclosed bedroom.

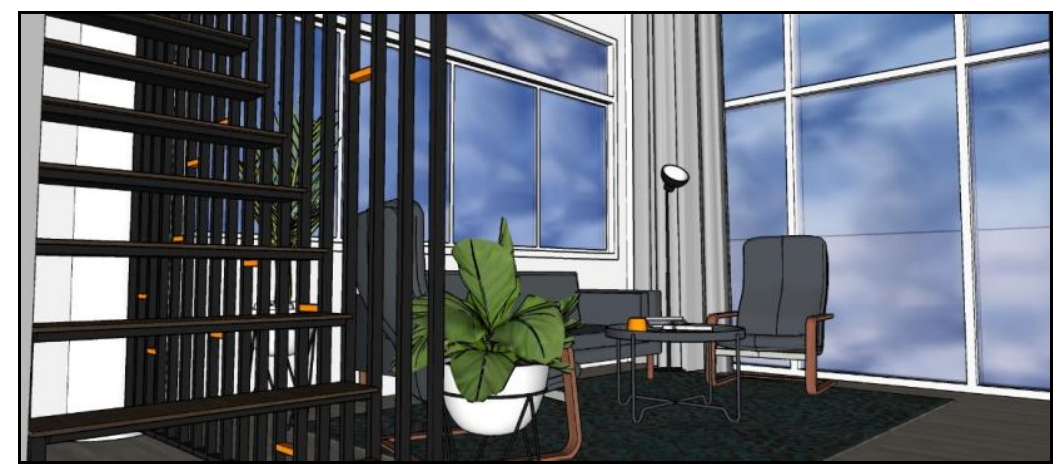

Figure 14. Interior Atmosphere of the design of Micro-Apartment in Pontianak

Sources: Author, 2020 


\section{Conclusion}

We can conclude that the design of Micro-apartement in Pontianak is a place that will offer privacy for each one of the residents without cutting the link with the others, and it will also try to offer new living standard to the population. The purpose of this design is to become a first step in the introduction of Micro-housing in Pontianak in order to reply to near demographic issues that aare inevitable, but the purpose of this design is also to introduce an architectural element to the town and hoping that it can attract people.

\section{Bibliography}

Central Bureau of Statistic. (2020, December 28). Hasil Sensus Penduduk 2020. Retrieved from: https://www.bps.go.id Central Bureau of Statistic of Pontianak. (2020, December 28). Jumlah Penduduk Menurut Kecamatan di Kota Pontianak, 1990, 2000, 2010. Retrieved from: https://pontianakkota.bps.go.id

Estaji, H. (2017). A Review of Flexibility and Adaptability in Housing Design. Journal of Contemporary Architecture, 4 , 37-49.

Florida, R. (2019, May 29). Young People's of Cities Isn't a Passing Fad. Retrieved from: http://www.bloomberg.com

Gabbe, C.J. (2015). Looking Through the Lens of Size: Land Use Regulations and Micro Apartments in San Francisco. San Francisco. Cityscape, 17, 223-237

Jones, S. (2017). Is There a Demande in The Future for Micro-Housing in Canada. Victoria, British Columbia, Canada: JONES-APRJ-699

Pandhi, N. ( 2017, Augustus 02). Furniture a necessity, not a luxury. Retrived from: http://www.ndtv.com

Patton, C.V. (1988). Spontaneous Shelter: International Perspectives and Prospects. Philadelphia: Temple University Press

Potikyan, M. (2017). Advantages and opportunities of developing and investing in microunits. Massachusetts: Massachusetts Institute of Technology

Said, C. ( 2013, November 3). Micro-apartment developments on rise in S.F. Micro-apartment dwellers live efficiently in tiny spaces. Retrieved from: https://www.sfhgates.com

Snyder, J.C., \& Catanase, A.J. (1989). Pengantar Arsitektur. Jakarta: Erlangga

Sullivan, B., \& Chen, K. (1997). Design for tenant fitout: a critical review of public housing flat design in Hong Kong. Hong Kong. Habitant International. 21(3), 291-303

Thogersen, K. (2017). Small Spaces Need Smart Solutions Designing Furniture for Small Spaces, in Connection With Human Wellbeing. Trondheim: Norwegian University of Science and Technology

Turner \& Jogn, FC. (1972). Freedom to Build, Dweller Control of the Housing Process. New York: The Macmillan Company

Urban Land Institute. (2017). The macro view on micro-unit. Washingtoon DC 20007-5201: Urban Lands Institute

US Census Bureau. (2020, December 28). Ranking Table of The World Population. Retrieved from: https://www.cencus.go

Waite, R. (2015, January 15). Micro-homes: part of the solution or part of the problem?. Retrieved from: $\underline{\text { http://architectsjournal.co.uk }}$ 